\title{
Effect of Electronic Banking on the Profitability of Deposit Money Banks in Nigeria
}

Abdulganiyu Jimoh

Chief Lecturer (M.Sc, MBA, B.Sc), Federal College of Education (Tech.), St. Finbarrs College Road, Akoka 100001, Lagos, Nigeria

\begin{tabular}{ll}
\hline DOI: $10.36348 /$ jaep.2019.v03i11.004 & | Received: 10.11.2019 | Accepted: 16.11 .2019 |Published: 24.11 .2019 \\
*Corresponding author: Abdulganiyu Jimoh &
\end{tabular}

*Corresponding author: Abdulganiyu Jimoh

\section{Abstract}

The study examined the effect of electronic banking on the profitability of deposit money Banks in Nigeria. Banking industry is confronted by a new innovation imposed by technology transformation that has changed the way banks conduct their activities from traditional means to electronic means. Furthermore, this study investigates how the electronic banking channels through internet, mobile, POS and ATM have impacted on deposit money banks profitability. It is against this background that the study examined the effect of electronic banking on the profitability of deposit money Banks in Nigeria. The methodology of the study was quantitative in nature. Using time series data of 2006 -2015 , the study employed regression technique in the analysis of sourced data. Data were collected from secondary sources through annual reports of deposit money Banks in Nigeria. Electronic banking was measured using the total values of internet banking, mobile banking, POS and ATM while Profitability was measured using profit margin of deposit money banks in Nigeria. Profitability was regressed on internet banking, mobile banking, POS and ATM using ordinary least square regression technique. The study revealed that positive relationship exists between mobile banking and Profitability, and between ATM and Profitability. In addition, there is also a statistically significant relationship between POS and Profitability while there is no significant relationship between internet banking and Profitability. As such, E-banking has a positive effect on Profitability of deposit money banks in Nigeria. It is therefore, recommended that banks must offer numerous services through internet banking and effective transaction through the POS Terminals.

Keywords: Electronic Banking, Profitability, Banks, Deposit Money Banks, Nigeria.

Copyright @ 2019: This is an open-access article distributed under the terms of the Creative Commons Attribution license which permits unrestricted use, distribution, and reproduction in any medium for non-commercial use (NonCommercial, or CC-BY-NC) provided the original author and sources are credited.

\section{INTRODUCTION}

The emergence of electronic banking has helped greatly to improve the operations of deposit money banks in Nigeria. The delivery of electronic services to businesses and consumers has been going on for decades. The electronic banking channels allows customers to use computers to access specific information from accounts and possibly conduct transactions from remote location quickly and successfully. Electronic banking is simply an electronic payment system which assist customers of any financial institution to conduct transaction.

Simpson, J [1] asserts that the prospects of reducing the cost of operations, revenue actually is seen as a motivator in the investment on electronic banking by banks. However, the adoption of electronic banking has brought notable challenges to the banking industry in terms of exposure to risk. Since the introduction of electronic banking, it has been noticed that the volume of deposits has increased, as well as fraudulent practices in Nigerian banks.

Freedman [2] proposes that electronic banking is made up of three devices; access cards, stored value cards and network money. Electronic money is the sum of network money and stored value cards. The most fascinating about this view is that electronic money and internet banking are no longer processes but devices, Shy and Tarkka [3] have presented models that identify conditions which alternative electronic payments substitute for cash.

The world has witnessed numerous electronic banking instruments meant to facilitate trade and simplify banking transactions. For many years, bankers, entrepreneurs and others have advocated for the replacement of physical cash and the introduction of more flexible, efficient and cost effective retail payment solutions [4]. 
However, not many studies have been done on the profitability of deposit money banks in Nigeria. The fact still remains the reality of using IT in banks is necessitated by the huge amount of information being handled by these banks on a daily basis.

Electronic banking has experienced tremendous growth and has transformed traditional practices in banking [5]. This study examines the effect of electronic banking on the profitability of deposit money banks in Nigeria

\section{Statement of the Problem}

Electronic banking technology holds the potential to fundamentally change banks and the banking industry. An extreme view speculates that the electronic banking will destroy old models of how bank services are delivered DeYoung [6]. The widespread availability of electronic banking is expected to affect the mixture of financial services produced by these banks. In addition, industry analysis outlining the potential impact of electronic banking on cost savings, revenue growth and risk profile of the banks have also generated considerable interest and speculation about the impact of the information technology on the banking industry.

However, the fact that electronic banking is fast gaining acceptance in Nigerian banking sector does not necessarily mean improved banks performance nor would continuous use of electronic banking as a delivery channel make it economically viable, productive or profitable. Apart from loss experienced by depositors, employees and other stakeholders, the level of confidence in the financial system has been negatively affected [7].

Traditional banking system was often characterized by delay and inefficiency in the delivery of financial services which led to the introduction of electronic banking. The introduction of electronic banking system which was supposed to bring about efficiency and effectiveness in service delivery, rather resulted to disappointment to customers [4].

The major difficulties users face in carrying out electronic payments are network (communication gaps between banks and network hosts) issues, literacy, concerns on risk and unreliable machines [8]. This study seeks therefore to address the effect of electronic banking on the profitability of deposit money banks in Nigeria.

\section{OBJECTIVE OF THE STUDY}

The main objective of the study is to examine the effect of electronic banking on the profitability of deposit money banks in Nigeria. Specifically, the study objectives are:
- To assess whether automated teller machine (ATM) has any effect on profitability of deposit money banks in Nigeria.

- To ascertain whether point of sales (POS) has any effect on profitability of deposit money banks in Nigeria.

- To determine whether internet banking has effect on profitability of deposit money banks in Nigeria.

- To examine whether mobile banking has any effect on profitability of deposit money banks in Nigeria.

\section{Research Questions}

The study was based on the following research questions:

- To what extent does automated teller machine (ATM) has any effect on profitability of deposit money banks in Nigeria?

- To what extent does point of sales (POS) has any effect on profitability of deposit money banks in Nigeria?

- To what extent does internet banking have any effect on profitability of deposit money banks in Nigeria?

- To what extend does mobile banking has any effect on profitability of deposit money banks in Nigeria?

\section{Research Hypotheses}

For the purpose of analyzing the data, the following hypotheses were tested:

$\mathrm{HO}_{1}$ : There is no significant relationship between automated teller machine (ATM) and profitability of deposit money banks in Nigeria.

$\mathrm{HO}_{2}$ : There is no significant relationship between point of sales (POS) and profitability of deposit money banks in Nigeria.

$\mathrm{HO}_{3}$ : There is no significant relationship between internet banking and profitability of deposit money banks in Nigeria.

$\mathrm{HO}_{4}$ : There is no significant relationship between mobile banking and profitability of deposit money banks in Nigeria.

\section{Significance of the study}

The study addresses the effect of electronic banking on the profitability of deposit money banks in Nigeria. With this study, deposit money banks are able to understand banking in a new dimension. It will help to highlight the various importance of electronic banking and increase profitability. This model will help the deposit money banks in gaining more money, enlighten managers of deposit money banks in Nigeria on how to serve customers and also gain better loyalty from customers. The study will also come up with recommendations that will help shareholders in the banking industry with new techniques to cope with 
Abdulganiyu Jimoh; J Adv Educ Philos, Nov 2019; 3(11): 405-413

electronic banking challenges and meeting customers' needs which are essential for enhancing profitability of deposit money banks in Nigeria. A number of studies $[9,10,4]$ have shown that electronic banking awareness is still very low, thereby hindering profitability of deposit money banks in Nigeria. This study will also help the general public by creating awareness on the benefits of electronic banking which hopefully will drastically reduce cash handling, thereby reducing the cost of printing of cash, processing cost, storage cost, insurance cost and the cost of moving cash.

\section{Scope of the Study}

This study is going to cover the ATM (Automated Teller Machines), POS (Point of Sale), Internet banking and Mobile banking channels which made up the electronic banking and profit margin of deposit money banks in Nigeria from 2006-2015. Banks could not be covered individually because of their inadequate disclosure on electronic banking investment.

\section{LITERATURE REVIEW}

Information and Communication Technology in Sub-Saharan Africa are rapidly changing the way business is conducted. Technology has resulted in new delivery systems for banking channels and services such as Telephone Banking, PC-Banking, and Electronic Funds Transfer at Point of Sale

Banks traditionally have always sought medium through which they would serve their customers more cost-effectively as well as augment the benefit to their clients. Their core concern has been to serve customers more conveniently, and in the process increase profits and competitiveness thus banking in Nigeria embracing the influx of e-banking. Electronic banking can be defined as the deployment of banking channels and services over electronic and communication networks directly to customers [11].

Electronic banking uses the internet as the delivery channel by which to conduct banking activities, for example, transferring funds, paying bills, viewing current and savings account balances, paying mortgages and purchasing financial instruments and certificates of deposits [12].

Electronic banking means the provision of information about the bank and its product via a website on the internet [13]. In Georgesan [14], electronic banking is defined as the provision of retail and small value banking products and services through electronic channels as well as large value electronic payments and other whole sale banking services delivered electronically. In Akinkumi [15] electronic banking enable financial institutions, customers and businesses to access accounts, transact business or obtain information on financial products and services through the internet. Customers access electronic banking services using an intelligent electronic device such as a personal computer (PC) personal digital assistant (PDA), Automated Teller Machine (ATM), among others.

Banking over the internet has attracted increasing intention from banks and other financial services industry, from participants, the business press, regulators and law makers, both in Nigeria and other countries.

Polatoglu \& Kin [16], stated that the vast majority of the banks that avoided electronic banking when it was first introduced, did so because they simply did not see the benefits of using it. However, electronic banking and communications technologies have been used extensively in banking in the recent years to promote the agenda of banks, and Deposit Money Banks in Nigeria has not been an exception

\section{Automated Teller Machine}

ATM card is made of a plastic having magnetic stride that hold all the information about the customer such as customer name, account, card number, card limit, concerned bank etc. According to [17], ATMs can be described as computer terminal, having record keeping system and cash vault in one unit, permitting customers to enter the bank's book keeping system with a card holding a Personal Identification Number (PIN) or by punching a special code number into the computer terminal linked to the bank's computerized records 24 hours a day.

This is an electronics device which allows a bank's customers to make cash withdrawals and check their account balances at any time without the need for a human teller. Many ATMs also allow people to deposit cash or cheques, transfer money between their bank accounts or even postage stamps. To withdraw cash, make deposits, or transfer funds between accounts, you generally insert an ATM card and enter your personal identification number (PIN). Some ATMs impose a surcharge, or usage fee, on consumer who are not member of their institution or on transactions at remote locations. ATMs must disclose the existence of a surcharge on the terminal screen or on a sign next to the screen.

\section{Mobile Banking}

A more current e-banking development is wireless internet applications of banking mostly called m-banking. With the combination of internet and mobile phone, a new service (mobile data service) is enabled and the first such wireless internet commercial transaction was performed by the banking industry [18].

Mobile banking involves the use of mobile phone for settlement of financial transactions. It supports person to person transfers with immediate availability of funds for the beneficiary. Mobile payment uses the card infrastructure for movement of 
payment instruction as well as secure Short Message Service (SMS) messaging for confirmation of receipt to the beneficiary. Mobile banking is meant for low value transactions where speed of completing the transaction is a key. The services are covered under this product include account enquiry, funds transfer, recharge phones, changing of passwords and bill payment which are offered by few institution [19].

\section{Telephone Banking}

Telephone banking is one that can be considered as a form of distance or virtual banking, which is basically the delivery of branch financial services via telecommunication devices where the bank's customers can perform retail banking transactions by calling a telephone or mobile communication unit, which is linked to an automated system of the bank by utilizing Automated Voice Response (AVR) technology" [20].

This is the most familiar of the tele-banking devices and it allows customers to transact banking business over the phone. It can be used as an alternative to the traditional branch banking or in conjunction with it $[21,22]$. The customer can access their accounts using telephone lines as a link to the financial institutions computer Centre. Services rendered here include account balance, transfer, change of pin etc. This product has also experienced low patronage due to inadequate awareness and education of the customer on how to maximally use their phone to transact simple banking operations [4].

\section{Internet Banking}

Internet banking uses technology and brings the bank closer to the customer. Internet banking refers to systems that enable bank customers to get access to their accounts and general information on bank products and services through the use of bank's website, without the intervention or inconvenience of sending letters, faxes, original signatures and telephone confirmations [23]. E-commerce is greatly facilitated by internet banking and is mostly used to effect payment. Internet banking also uses the electronic card infrastructure for executing payment instructions and for final settlement of goods and services over the internet between the merchant and the customer, currently the most common internet payments are for customer bills and purchase of air tickets through the websites of the merchants [24]. If one has access to the internet and a computer, all they need to do is proceed to their banks website and login. From there they have access to all of their accounts that they have at bank. Transfer funds between accounts with ease. One can also use online banking to see how much money they have in their accounts and can also trace all their transactions.

\section{METHODOLOGY}

The quantitative research design was adopted for this study. This is in line with the research design adopted by Hassan, Mamman and Farouk [25]. The population of the study consists of all the 15 deposit money banks in Nigeria. Secondary source of data was used for this study, and the data were sourced from the annual reports of Deposit Money Banks in Nigeria. The study covers the periods between 2006-2015.

The key variables of Profitability were measured in relation to deposit money banks in the study are Profit margin (EBIT). This will constitute the dependent variables. While the independent variables of Electronic banking that were measured are ATM, POS, internet and mobile banking. The technique of data analysis that was adopted for this study is inferential statistics. Ordinary Least Square Regression Equation was used to find out whether relationship exist between Electronic banking variables and Profitability variables identified in the study. If relationship exists, what is the nature of the relationship?

The Profitability (PR) was regressed on automated teller machines (AT), Point of sales Terminals (PS), internet banking (IB) and mobile banking (MB) using the researcher's model. The model is stated below:

$\mathrm{PR}=\mathrm{b}_{0+} \mathrm{b}_{1} \mathrm{AT}+\mathrm{b}_{2} \mathrm{PS}+\mathrm{b}_{3} \mathrm{IB}+\mathrm{b}_{4} \mathrm{MB}+\mathrm{e}$

Where,

$$
\begin{aligned}
& \text { PR = Profitability } \\
& b_{0}=\text { Intercept } \\
& b_{1}, b_{2}, b_{3}, b_{4}=\text { Parameters of regression model } \\
& \text { AT = Value automated teller machines } \\
& \text { PS = Value of point of sales } \\
& \text { IB = Value of internet banking } \\
& \text { MB = Value of mobile banking } \\
& \text { e = Error Term }
\end{aligned}
$$

The Profitability (PR) was regressed on automated teller machines (AT), Point of sales Terminals (PS), internet banking (IB) and mobile banking (MB) using the researcher's model as stated below:

$\mathrm{PR}=\mathrm{b}_{0+} \mathrm{b}_{1} \mathrm{AT}+\mathrm{b}_{2} \mathrm{PS}+\mathrm{b}_{3} \mathrm{IB}+\mathrm{b}_{4} \mathrm{MB}+\mathrm{e}$

The estimation of the coefficients of the models and interpretation were done using SPSS version 23 in order to test the robustness of the models.

\section{RESULTS AND DISCUSSIONS}

This section presents the results and discussion of the hypotheses tested.

\section{Test of Hypotheses}

Secondary data was used in testing the study hypotheses. Information relating to automated teller machines, point of sales, internet banking, mobile banking and profitability of deposit money banks in 
Nigeria for the period 2006-2015 were gathered from the banks' annual reports.

\section{Test of Hypotheses One, Two, Three and Four}

Test of the hypotheses one, two, three and four were done using ordinary least square regression model generated from the secondary data sample for the study. The model is re-stated as follows:

$$
\mathrm{PR}=\mathrm{b}_{0+} \mathrm{b}_{1} \mathrm{AT}+\mathrm{b}_{2} \mathrm{PS}+\mathrm{b}_{3} \mathrm{IB}+\mathrm{b}_{4} \mathrm{MB}+\mathrm{e}
$$

The hypotheses are re-stated below:

$\mathrm{HO}_{1}$ : There is no significant relationship between automated teller machine (ATM) and profitability of deposit money banks in Nigeria.

$\mathrm{HO}_{2}$ : There is no significant relationship between point of sales (POS) and profitability of deposit money banks in Nigeria.

$\mathrm{HO}_{3}$ : There is no significant relationship between internet banking and profitability of deposit money banks in Nigeria.

$\mathrm{HO}_{4}$ : There is no significant relationship between mobile banking and profitability of deposit money banks in Nigeria.

Appendix 1 presents the coefficients of model fitness on how effective electronic banking variables explain profitability of deposit money banks in Nigeria. The profitability has an overall correlation with electronic banking of 0.923 which is strong and positive. Thus, the goodness of fit embedded in the adjusted coefficient of determination shows that the estimated model has high predictive power. Electronic banking variables that are included in the model explain $86.1 \%$ of the changes or variations in profitability of deposit money banks in Nigeria. This shows that $13.9 \%$ of the variations in profitability is explained by other factors not captured in the model.

Appendix 1 also revealed that the DurbinWatson statistics of 1.613 confirm non-auto correlation of random variables. The DW statistics can vary between 0 and 4 with a value of 2 meaning that the residuals are uncorrelated [26].

Appendix 1 also revealed that the F-statistics is statistically significant, as confirmed by the P-value of
0.005 , this is a testimony of joint significant of estimated coefficient of electronic banking. It indicates that the model is statistically significant in explaining the relationship between profitability and electronic banking at a $95 \%$ level of significance. The analysis of variance of the predictors of the model have a significance of 0.005 and fails to accept the null hypothesis and conclude that electronic banking have a positive effect on profitability of deposit money banks in Nigeria.

Appendix 1 also revealed that the regression coefficients of the predictors (Electronic banking) are presented. Results indicate that INT do not have significant influence on profitability of deposit money banks in Nigeria. Therefore, we fail to reject the null hypothesis. ATM, POS and MOB are significant in explaining profitability of deposit money banks in Nigeria. Due to this finding we fail to accept the null hypothesis and conclude that POS, INT and MOB have a positive statistically significant effect on the profitability of deposit money banks in Nigeria.

These findings are corroborated by findings on E-banking and bank profitability by Sana, Mohammad, Hassan and Momina [27] in a study conducted in Pakistan that found that electronic banking reduced costs, saved time, improved accuracy, improved reliability and quality of services and eventually led to improved profitability for the banks. Additionally, Nofie [28] found that a higher usage of electronic retail payment instruments seems to stimulate banking business leading to better bank performance dominated by fee income.

The results of the regression estimating confirm the multiplier effect created through money transfer through the E-banking system. Money transfer to or from a bank generates fees income and when the money reaches the other bank there are multiple of transactions that may arise from that money. It can be used to pay liabilities or it can be invested as a deposit by the customer and hence providing an opportunity for the bank to lend out the money and hence earn interest income over the tenure of the deposit. This means that E-banking has both direct and indirect ways of boosting bank profitability.

\section{APPENDIX I}

Regression Results for Dependent and Independent Variables

\begin{tabular}{|c|c|c|c|c|c|c|}
\hline \multicolumn{7}{|c|}{ Coefficients $^{\mathrm{a}}$} \\
\hline \multirow{2}{*}{\multicolumn{2}{|c|}{ Model }} & \multicolumn{2}{|c|}{ Unstandardized Coefficients } & \multirow{2}{*}{$\begin{array}{l}\text { Standardized Coefficients } \\
\text { Beta }\end{array}$} & \multirow[t]{2}{*}{$\mathrm{t}$} & \multirow[t]{2}{*}{ Sig. } \\
\hline & & $\mathrm{B}$ & Std. Error & & & \\
\hline \multirow[t]{5}{*}{1} & (Constant) & 827791446.275 & 203911964.803 & & 4.060 & .010 \\
\hline & ATM & 431.712 & 133.285 & .979 & 3.239 & .023 \\
\hline & POS & 752.822 & 7444.953 & .181 & .101 & .923 \\
\hline & INT & 1717.592 & 2832.915 & .090 & .606 & .571 \\
\hline & MOB & -1014.606 & 7138.905 & -.256 & -.142 & .893 \\
\hline
\end{tabular}


Abdulganiyu Jimoh; J Adv Educ Philos, Nov 2019; 3(11): 405-413

\begin{tabular}{|c|c|c|c|c|c|c|c|c|}
\hline \multicolumn{9}{|c|}{ Model Summary ${ }^{b}$} \\
\hline \multirow[t]{2}{*}{ Model } & \multirow[t]{2}{*}{$\mathrm{R}$} & \multirow{2}{*}{$\begin{array}{l}\mathrm{R} \\
\text { Square }\end{array}$} & \multirow{2}{*}{$\begin{array}{l}\text { Adjusted R } \\
\text { Square }\end{array}$} & \multirow{2}{*}{$\begin{array}{l}\text { Std. Error of the } \\
\text { Estimate }\end{array}$} & \multicolumn{3}{|c|}{ Change Statistics } & \multirow{2}{*}{$\begin{array}{l}\text { Durbin- } \\
\text { Watson }\end{array}$} \\
\hline & & & & & $\begin{array}{l}\mathrm{R} \text { Square } \\
\text { Change }\end{array}$ & $\begin{array}{l}\mathrm{F} \\
\text { Change }\end{array}$ & $\begin{array}{l}\text { Sig. F } \\
\text { Change }\end{array}$ & \\
\hline 1 & $.961^{\mathrm{a}}$ & .923 & .861 & 239333317.788 & .923 & 14.932 & .005 & 1.613 \\
\hline \multicolumn{9}{|c|}{ a. Predictors: (Constant), MOB, INT, ATM, POS } \\
\hline b. & 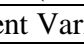 & RU & & & & & & \\
\hline
\end{tabular}

Source: SPSS version 23

\section{Hypothesis One}

Appendix 2 presents the coefficients of model fitness on how effective ATM explain profitability of deposit money banks in Nigeria. The profitability has an overall correlation with ATM of 0.916 which is strong and positive. Thus, the goodness of fit embedded in the adjusted coefficient of determination shows that the estimated model has high predictive power. Automated teller Machine can explain $90.6 \%$ of the changes or variations in profitability of deposit money banks in Nigeria. Appendix 2 also revealed that the Durbin-Watson statistics of 1.411 confirm non-auto correlation of random variables. The DW statistics can vary between 0 and 4 meaning that the residuals are uncorrelated [26].

Appendix 2 also revealed that the F-statistics is statistically significant, as confirmed by the P-value of 0.000 , this is a testimony of statistically significance of estimated coefficient of ATM. It indicates that the model is statistically significant in explaining the relationship between profitability and ATM at a 95\% level of significance. The analysis of variance of the model have a significance of 0.000 and fails to accept the null hypothesis and conclude that ATM have a positive effect on profitability of deposit money banks in Nigeria.

\section{APPENDIX II}

Regression Results for Dependent and Independent Variables

\begin{tabular}{|c|c|c|c|c|c|c|c|c|}
\hline \multicolumn{9}{|c|}{ Model Summary ${ }^{b}$} \\
\hline \multirow[t]{2}{*}{ Model } & \multirow[t]{2}{*}{$\mathrm{R}$} & \multirow{2}{*}{$\begin{array}{l}\mathrm{R} \\
\text { Square }\end{array}$} & \multirow{2}{*}{$\begin{array}{l}\text { Adjusted R } \\
\text { Square }\end{array}$} & \multirow{2}{*}{$\begin{array}{l}\text { Std. Error of the } \\
\text { Estimate }\end{array}$} & \multicolumn{3}{|c|}{ Change Statistics } & \multirow{2}{*}{$\begin{array}{l}\text { Durbin } \\
\text { Watson }\end{array}$} \\
\hline & & & & & $\begin{array}{l}\mathrm{R} \text { Square } \\
\text { Change }\end{array}$ & $\begin{array}{l}\text { F } \\
\text { Change }\end{array}$ & $\begin{array}{l}\text { Sig. F } \\
\text { Change }\end{array}$ & \\
\hline 1 & $.957^{\mathrm{a}}$ & .916 & .906 & 197056250.329 & 916 & 87.481 & .000 & 1.411 \\
\hline \multicolumn{9}{|c|}{ a. Predictors: (Constant), ATM } \\
\hline b. De & it $\mathrm{V}$ & e: PRC & & & & & & \\
\hline
\end{tabular}

Source: SPSS version 23

\section{Hypothesis Two}

Appendix 3 shows the effectiveness of the model in measuring the effect of point of sales on profitability of deposit money banks in Nigeria. The overall correlation coefficient $(\mathrm{R})$ between profitability and point of sales is a strong positive correlation of 0.731. The coefficient of determination ( $R$ Square adjusted) indicates that point of sales in the regression model can explain $70 \%$ of the variations in profitability of deposit money banks in Nigeria holding other factors constant. Appendix 3 also revealed that the DurbinWatson statistics of 0.704 confirm non-auto correlation of random variables. The DW statistics can vary between 0 and 4 meaning that the residuals are uncorrelated [26].

Appendix 3 presents the analysis of variance of the point of sales that are included to explain the profitability of deposit money banks in Nigeria. The overall significance of the model is 0.002 which is at level of significance of $95 \%$ and fail to accept the null hypothesis and conclude that point of sales have statistically significant effect on profitability of deposit money banks in Nigeria. This shows that point of sales in the regression model have statistical significance in explaining the profitability of deposit money banks in Nigeria.

\section{APPENDIX III}

\begin{tabular}{|c|c|c|c|c|c|c|c|c|}
\hline \multicolumn{9}{|c|}{ Regression Results for Dependent and Independent Variables } \\
\hline \multicolumn{9}{|c|}{ Model Summary ${ }^{b}$} \\
\hline \multirow[t]{2}{*}{ Model } & \multirow[t]{2}{*}{$\mathrm{R}$} & \multirow{2}{*}{$\begin{array}{l}\mathrm{R} \\
\text { Square }\end{array}$} & \multirow{2}{*}{$\begin{array}{l}\text { Adjusted R } \\
\text { Square }\end{array}$} & \multirow{2}{*}{$\begin{array}{l}\text { Std. Error of the } \\
\text { Estimate }\end{array}$} & \multicolumn{3}{|c|}{ Change Statistics } & \multirow{2}{*}{$\begin{array}{l}\text { Durbin- } \\
\text { Watson }\end{array}$} \\
\hline & & & & & $\begin{array}{l}\mathrm{R} \text { Square } \\
\text { Change }\end{array}$ & $\begin{array}{l}\mathrm{F} \\
\text { Change }\end{array}$ & $\begin{array}{l}\text { Sig. F } \\
\text { Change }\end{array}$ & \\
\hline 1 & $.855^{\mathrm{a}}$ & .731 & .697 & 353282321.886 & .731 & 21.707 & .002 & .704 \\
\hline \multicolumn{9}{|c|}{ a. Predictor } \\
\hline
\end{tabular}

Source: SPSS version 23 


\section{Hypothesis Three}

The indicators of the model fitness are shown on Appendix 4. The coefficients indicate that the correlation coefficient ( $\mathrm{R}$ Square) between the independent variable and profitability is 0.298 which is a positive relationship. The coefficient of determination ( $\mathrm{R}$ Square adjusted) of 0.210 indicates that the model can explain only $21 \%$ of the variations or changes in the dependent variable of profitability. In other words, internet banking can explain only $21 \%$ of changes in profitability of deposit money banks in Nigeria.

Appendix 4 presents the analysis of variance (ANOVA) on the effect of electronic banking on the profitability of deposit money banks in Nigeria. The results indicate that the model at a level of significance of $95 \%$, is not statistically significant in explaining the effect of electronic banking on the profitability of deposit money banks in Nigeria. Put differently, it means that the ANOVA results indicate that internet banking is not statistically significant in explaining variations in profitability of deposit money banks in Nigeria with a 0.103 level of significance and fail to reject the null hypothesis and conclude that internet banking has no statistically significant effect on profitability of deposit money banks in Nigeria.

\section{APPENDIX IV}

Regression Results for Dependent and Independent Variables

\begin{tabular}{|c|c|c|c|c|c|c|c|c|}
\hline \multicolumn{9}{|c|}{ Model Summary $^{\text {b }}$} \\
\hline \multirow[t]{2}{*}{ Model } & \multirow[t]{2}{*}{$\mathrm{R}$} & \multirow{2}{*}{$\begin{array}{l}\mathrm{R} \\
\text { Square }\end{array}$} & \multirow{2}{*}{$\begin{array}{l}\text { Adjusted } \\
\text { R Square }\end{array}$} & \multirow{2}{*}{$\begin{array}{l}\text { Std. Error of the } \\
\text { Estimate }\end{array}$} & \multicolumn{3}{|c|}{ Change Statistics } & \multirow{2}{*}{$\begin{array}{l}\text { Durbin- } \\
\text { Watson }\end{array}$} \\
\hline & & & & & $\begin{array}{l}\text { R Square } \\
\text { Change }\end{array}$ & $\begin{array}{l}\mathrm{F} \\
\text { Change }\end{array}$ & $\begin{array}{l}\text { Sig. F } \\
\text { Change }\end{array}$ & \\
\hline 1 & $.546^{\mathrm{a}}$ & .298 & .210 & 570505941.135 & .298 & 3.391 & .103 & .574 \\
\hline \multicolumn{9}{|c|}{ a. Predictors: (Constant), INT } \\
\hline \multicolumn{9}{|c|}{ b. Dependent Variable: PROF } \\
\hline
\end{tabular}

Source: SPSS version 23

\section{Hypothesis Four}

The robustness of the regression model is presented in Appendix 5. The results indicate that the overall correlation between profitability and mobile banking is 0.732 which is a positive and strong correlation. The coefficient of determination is indicated by $\mathrm{R}$ square (adjusted) of 0.699 showing that mobile banking can explain $69.9 \%$ of the variations in profitability. There are other factors that can explain $30.1 \%$ variations in changes in profitability. Appendix 2 also revealed that the Durbin-Watson statistics of 0.721 confirm non-auto correlation of random variables. The
DW statistics can vary between 0 and 4 meaning that the residuals are uncorrelated [26].

Appendix 5 shows the overall significance of mobile banking in explaining profitability of deposit money banks in Nigeria. At a level of significance of $95 \%$, mobile banking is significant in explaining changes in profitability of deposit money banks in Nigeria with a 0.002 level of significance and fails to accept the null hypothesis and conclude that mobile banking has a positive influence of profitability of deposit money banks in Nigeria.

\section{APPENDIX V}

Regression Results for Dependent and Independent Variables

\begin{tabular}{|c|c|c|c|c|c|c|c|c|}
\hline \multicolumn{9}{|c|}{ Model Summary $^{b}$} \\
\hline \multirow[t]{2}{*}{ Model } & \multirow[t]{2}{*}{$\mathrm{R}$} & \multirow{2}{*}{$\begin{array}{l}\mathrm{R} \\
\text { Square }\end{array}$} & \multirow{2}{*}{$\begin{array}{l}\text { Adjusted } \\
\text { R Square }\end{array}$} & \multirow{2}{*}{$\begin{array}{l}\text { Std. Error of the } \\
\text { Estimate }\end{array}$} & \multicolumn{3}{|c|}{ Change Statistics } & \multirow{2}{*}{$\begin{array}{l}\text { Durbin- } \\
\text { Watson }\end{array}$} \\
\hline & & & & & $\begin{array}{l}\text { R Square } \\
\text { Change }\end{array}$ & $\begin{array}{l}\mathrm{F} \\
\text { Change }\end{array}$ & $\begin{array}{l}\text { Sig. F } \\
\text { Change }\end{array}$ & \\
\hline 1 & $.856^{\mathrm{a}}$ & .732 & .699 & 352340772.533 & .732 & 21.866 & .002 & .721 \\
\hline
\end{tabular}

\section{Source: SPSS version 23}

\section{Summary of Findings}

Evidence from previous studies on whether electronic banking affect profitability showed that there were mixed results based on the operating environment and the level of adoption. In Nigeria there is a high level of adoption of electronic banking in the banking sector.
The findings of the study revealed that the combined effect of electronic banking affect profitability of deposit money banks positively.

The findings of the study showed a positive effect of electronic banking on profitability of deposit money banks in Nigeria. Findings on the effect of electronic banking on profitability of deposit money banks in Nigeria showed that variations in profitability 
Abdulganiyu Jimoh; J Adv Educ Philos, Nov 2019; 3(11): 405-413

can be explained by electronic banking. This finding is further supported by regression results which showed that electronic banking has a statistically significant influence on the profitability of deposit money banks in Nigeria and therefore the alternate hypothesis was accepted.

Results also revealed that point of sales had positive effect on profitability of deposit money banks in Nigeria. This is supported by the coefficient of determination which shows that point of sales explains the variations in profitability of deposit money banks in Nigeria. The test for significance also showed that the influence was statistically significant and hence the alternate hypothesis was accepted. This means that point of sales is good at skimming out incomes and having a good return to the banks' initial outlay.

The findings revealed that internet banking have no significant effect on the profitability of deposit money banks in Nigeria. This finding is supported by the coefficient of determination which shows that there were low variations in profitability as explained by internet banking. The influence of internet banking on profitability is also not significant and hence the null hypothesis was accepted. This suggest that banks are at an early stage in the usage of some internet banking and due to such short time, profitability may not have been affected by internet banking to a great extent.

The results showed that mobile banking have a positive influence on profitability of deposit money banks in Nigeria. The analysis produced a coefficient of determination which showed that there were high percentage of variations in profitability which is explained by mobile banking. The significance test showed that influence of mobile banking on bank profitability was statistically significant and hence the alternate hypothesis was accepted.

\section{CONCLUSION}

Based on the findings of the study, it can be concluded that electronic banking have positive significant effect on profitability of deposit money banks in Nigeria. The usage of electronic banking channels by deposit money banks in Nigeria has a high potential of improving profitability and hence better returns to the shareholders. The versatility of electronic banking has made their acceptance rate to be high among both the banks and their customers. It could have been challenging if the acceptance was only with either the banks or the customers. Banks in Nigeria have continued to high turnover even when other sectors of the economy show low profitability. This can be explained by the use of innovations which have enabled banks to start making income away from traditional sources like interest, trade and asset financing. Banks have been able to make more commission income from transactions done on electronic banking channels like; mobile phones, credit cards and point of sale terminals. In addition, this study showed that customers patronize E-banking channels such as ATM more than internet banking. This is because they derive certain benefits from the use of these products predominantly time saving, easy access to cash and convenience in the use of the products. And also they believed it was safer and much secure than the internet banking. In general conclusion the electronic banking has made banking transaction to be much easier by bringing services closer to its customers and safer, preventing the carrying of huge sums of money.

\section{RECOMMENDATIONS}

Deposit Money Banks through E-banking offers several opportunities to customers and they derive benefits from its usage. There were certain limitations in this study and the following recommendations were made:

- The bank should provide more ATM facilities; these should be placed at vantage locations within the city to reduce distance and time use in accessing the facility.

- Deposit Money Bank must improve and modernize its IT policies by ensuring that Communication Equipment's, Computers and other IT infrastructures to a large extent are managed by qualified staff to ensure that customers can enjoy better E-banking experience.

- Marketing and education of E-banking services and products should be intensified to attract more customers.

- The bank should conduct further research to find new E-banking channels to attract and to retain their current customers.

- Government should pursue a strategy to provide incentives for technology transfer from more developed economies in order to promote the usage of world class electronic banking channels.

- System developers need to create enhanced and effective security systems which can detect, control, prevent and manage fraud incidents on the various electronic banking channels.

\section{REFERENCES}

1. Simpson, J. (2002). The impact of the Internet in banking: observations and evidence from developed and emerging markets. Telematics and Informatics, 19(4), 315-330.

2. Freedman, K. (2000). Context as a part of visual culture. Journal of Cultural Research in Art Education, 18, 41.

3. Shy, O., \& Tarkka, J. (2002). The market for electronic cash cards. Journal of Money, Credit and Banking, 299-314. 
Abdulganiyu Jimoh; J Adv Educ Philos, Nov 2019; 3(11): 405-413

4. Siyanbola, T. T. (2013). The Influence of Cashless Banking on Nigerian Economy. E-Canadian Journal of Accounting and Finance, 1(2), 9-19.

5. Gonzalez, M. C., Hidalgo, C. A., \& Barabasi, A. L. (2008). Understanding individual human mobility patterns. nature, 453(7196), 779.

6. DeYoung, R. (2005). The performance of internetbased business models: Evidence from the banking industry. Journal of Business, 78(3), 893947.

7. Bosede, A. F., \& Olubukunola, U. (2013). Returns on Investment of Deposit Money Banks in Nigeria. Journal of Applied Finance and Banking, 3(3), 195-206.

8. Agbaje, O., \& Ayanbadejo, K. (2013). Electronic Payment and Economic Growth in Nigeria. A Report by RTC Advisory Services Ltd.

9. Sabi, H. M. (2014), Research Trends in the Diffusion of Internet Banking in Developing Countries. Journal of Internet Banking and Commerce, 19(2); In Auta, E. M. (eds). E-Banking in Developing Economy: Empirical Evidence from Nigeria. Journal of Applied Quantitative Methods, 5(2), 212-222.

10. Dogarawa, A. B. (2005). The Impact of E-banking on Customer Satisfaction in Nigeria. [Online] Available: http://mpra.ub.uni-muenchen.de/23200/ (September 15, 2013).

11. Malhotra, P., \& Singh, B. (2009). The impact of internet banking on bank performance and risk: The Indian experience. Eurasian Journal of Business and Economics, 2(4), 43-62.

12. Mohammed, S. K., Siba, S. M., \& Sreekumar, S. (2009). Service quality evaluation in internet banking: An empirical study in India. International Journal of Indian Culture and Business Management, 2(1).

13. Akinyele, S. T., \& Olorunleke, K. (2010). Technology and Service Quality in the Banking Industry: An Empirical Study on the Various Factors of Electronic Banking". International Journal of Business Management, 4(4), 209-221.

14. Georgesan., \& AS, O. (2008). Impact of Electronic Banking Instruments on the Intermediation Efficiency of the Nigerian Economy.

15. Akinkunmi, M. A. (2017). Determinants of Banks' Profitability in Nigeria: Does Relative Market Power Matter?. Journal of Finance and Bank Management, 5(1):42-53, In Aburine, T. U. (eds) Determinants of Bank Profitability: Macroeconomic evidence from Nigeria, Deaken University, working paper, 1-10
16. Nui Polatoglu, V., \& Ekin, S. (2001). An empirical investigation of the Turkish consumers' acceptance of Internet banking services. International journal of bank marketing, 19(4), 156-165.

17. Rose, P. S. (2005) Commercial Bank Management; $5^{\text {th }}$ Edition McGraw-Hill Irwin

18. Barnes, S. J., \& Corbitt, B. (2003). Mobile banking: concept and potential. International Journal of Mobile Communications, 1(3), 273 288.

19. Sathye, M. (2005). The impact of internet banking on performance and risk profile: Evidence from Australian credit unions. Journal of Banking Regulation, 6(2), 163-174.

20. Balachandher, K. G., Santha, V., Norhazlin, I., \& Rajendra, P. (2001). Electronic Banking in Malaysia: A Note on Evolution of Services and Consumer Reactions.

21. Kaplan, S. (1997). The words of risk analysis. Risk analysis, 17(4), 407-417.

22. Agboola, A. (2006). Information and communication technology (ICT) in banking operations in Nigeria: An evaluation of recent experiences. From http://unpan1.un.org/intradoc/groups/public/docu ments/AAPAM/UNPAN026533.pdf. Retrieved on 18th August 2011

23. Thulani, D., Tofara, C., \& Langton, R. (1970). Adoption and use of internet banking in Zimbabwe: An exploratory study. The Journal of Internet Banking and Commerce, 14(1), 1-13.

24. Littler, D., \& Melanthiou, D. (2006). Consumer perceptions of risk and uncertainty and the implications for behaviour towards innovative retail services: the case of internet banking. Journal of retailing and consumer services, 13(6), 431-443.

25. Hassan, S. U., Mamman, A., \& Farouk, M. A. (2013). Electronic Banking Products and Performance of Nigerian Deposit Money Banks. American Journal of Computer Technology and Application, 1(10), 138-145.

26. Field, A. (2009). Discovering Statistics Using SPSS (3rd ed.). London: Sage Publishers Ltd.

27. Sumra, S. H., Manzoor, M. K., Sumra, H. H., \& Abbas, M. (2011). The impact of e-banking on the profitability of banks: A study of Pakistani banks. Journal of Public Administration and Governance, 1(1), 31-38.

28. Nofie, I. (2011). The diffusion of electronic banking in Indonesia. Manchester Business School. 